\title{
FACTORS AFFECTING THE RETENTION OF KNOWLEDGE WORKERS
}

\author{
MARGIE SUTHERLAND \\ WILHELM JORDAAN \\ Department of Human Resource Management \\ Rand Afrikaans University
}

\begin{abstract}
One of the characteristics of knowledge workers is their high level of mobility. The cost of labour turnover of these key resources is high in both financial and non financial terms. There is thus a need to understand what the factors are that underpin the retention cognitions of knowledge workers. Data was collected from 306 knowledge workers in full time employment representing a wide range of demographic groupings. The results showed that job satisfaction and organisational commitment do not predict knowledge workers' proposed future length of service. Factor analysis revealed seven underlying dimensions of retention cognitions. Cluster analysis revealed nine distinct clusters of knowledge workers with regard to their retention cognitions. High levels of individualism, need for challenge and focus on personal development were demonstrated. The implications of these findings are discussed.
\end{abstract}

\section{OPSOMMING}

Een van die eienskappe van kenniswerkers is hulle hoë vlak van mobiliteit. Die koste van arbeidsomset van hierdie sleutelbronne is hoog in beide finansiële en nie-finansiële terme. Daar bestaan dus 'n behoefte om die faktore wat onderliggend is aan die retensiekognisies van kenniswerkers te verstaan. Data is ingesamel van 306 kenniswerkers in voltydse diens wat 'n wye reeks demografiese groeperings verteenwoordig. Die resultate dui daarop dat werktevredenheid en organisasieverbondenheid nie die kenniswerkers se verwagte lengte van diens voorspel nie. Faktorontleding het sewe onderliggende dimensies van retensiekognisies blootgelê. 'n Bondelontleding het nege duidelike bondels van kenniswerkers ten opsigte van hulle retensiekognisies onderskei. Hoë vlakke van individualisme, behoefte aan uitdaging en fokus op persoonlike ontwikkeling is aangedui. Die implikasies van hierdie bevindinge word bespreek.

It is often said that an organisation is only as good as its people and that knowledge workers are a major source of competitive advantage in a world where most processes and systems have been standardised across industry participants (Templer \& Cawsey, 1999). Attracting and retaining intellectual capital, a cadre of highly skilled, independent, internationally marketable and mobile individuals, is a critical feature of globalisation (Paul, 2000). For this reason, an organisation's ability to retain knowledge workers is a critical component in determining its present and future success. The financial impact of knowledge worker turnover is under-appreciated by organisations as the hidden nature of turnover costs, such as loss of organisational memory, conceals its true magnitude (Corporate Leadership Council, 1998a).

The attrition of knowledge workers has been viewed as a major cause for concern for the management of organisations. In what has been termed "the war for talent" (Tulgan, 2001), the job mobility of executives and knowledge workers is increasing (Chambers, Foulon, Handfield-Jones, Hankin \& Michaels, 1998). In the changing world of work, the psychological contract between employer and employee has changed fundamentally (Lee, 2001) and long term commitment to an organisation is no longer expected by either party (Armstrong \& Murlis, 1998). Furthermore, Friedman, Hatch and Walker (1998) write that the notion of a permanent job has become an oxymoron. As organisations become increasingly dependent on knowledge workers, paradoxically these workers' tenure seems to reduce. Bussin (2002) reports that the issue of increasing retention and decreasing turnover has become paramount in organisational life, and that attracting and retaining key talent has become a critical organisational competency. The literature on retention mentions the need for organisations to develop and communicate winning employee value propositions (Chambers et al., 1998). However, there is a paucity of empirical research on what the key components of such a proposition must be in order for the retention of key employees to be enhanced.

Requests for copies should be addressed to: M Sutherland, Department of Human Resource Management, RAU, PO Box 524, Auckland Park, 2006
The literature review set out below shows that fifty years of academic research on labour turnover has, in many ways, led to more questions than answers. Most studies have tested extremely highly focused hypotheses, were carried out in single companies or industries, looked at turnover and not retention factors, and/or were carried out prior to the new knowledge economy (Morrell, Loan-Clarke \& Wilkinson, 2001). Thus the aim of this research was to determine what the underlying retention factors are that are important to knowledge workers and whether or not these factors are universal, or if there are segments in the population of knowledge workers that desire different retention devices.

\section{LITERATURE REVIEW}

There is a plethora of academic literature available on the many facets of labour turnover, retention and knowledge workers, which serve as the main variables of this research.

\section{The knowledge economy}

The world economy has progressed from an industrial economy to a knowledge economy (Pine \& Gilmore, 1998). With knowledge being viewed as a major contributing factor to organisational success, the purveyors of this knowledge in organisations deserve to be focused on. Drucker (1974) first used the term "knowledge worker"; he described these individuals as employees who carry knowledge as a powerful resource which they, rather than the organisation, own. Drucker (1989: 175) states "Knowledge workers know that their knowledge.... gives them freedom to move since everyone's knowledge has a multitude of applications in the information or knowledge age". A few years later Drucker $(2002$, p. 76) wrote that knowledge workers have become the major creator of wealth and jobs and "...increasingly the success and even the survival of every business will depend on the performance of its knowledge workforce". He goes on to say that the knowledge economy will increasingly depend on higher levels of education. Harrigan and Dalmia (1991) define knowledge workers as key employees who create intangible value-adding assets, and who often transport 
those assets in their heads when they change employers. Brown and Duguid (1996) redefine the concept of a knowledge worker as a "learning person" who is at the core of knowledge transfer in an organisation.

One of the key features of knowledge workers in the new world of work is their increasing mobility and the consequences of this to the organisation. The mobility of these knowledge workers is a major concern in the new economy as the loss of knowledge workers to an organisation means loss of both tangible and intangible knowledge and possibly competitive advantage (Kinnear \& Sutherland, 2000). Templer and Cawsey (1999) regard knowledge workers as having portfolio careers, meaning that they have a portfolio of skills that they sell to a range of clients.

The new world of work has led to transitions in the employer/employee relationship over time. Tulgan (2001) identifies three stages within this relationship. The first phase was when employers gave up the notion of life-time employment. This was followed by the second phase where employees took responsibility for their own careers. The third - the current phase - is one of a mutual balance of power between employer and employee. This series of transitions has lead to dramatic changes in psychological contracts. Dibble (1999) notes that one of the characteristics of the new contract is that employees continually change jobs throughout their career in an attempt to ensure the best for themselves. In addition, Despres and Hiltrop (1995) define part of the change from traditional work to knowledge work as being characterised by a shift in the employee's loyalty from the organisation and its career systems to the knowledge worker's own profession, networks and peers. Hence, a significant consequence of the change in the psychological contract is the increased mobility of knowledge workers. Knowledge workers are seen to be fundamentally different from workers in the industrial economy and have their own unique conception of what represents job satisfaction (Kinnear, 1999) and, hence, focused research needs to be carried out on what drives the various aspects of their performance and, especially, their mobility.

\section{Labour turnover}

Trevor (2001) reports that over 1000 academic studies have been carried out on labour turnover. Despite the information gained from these studies, Fitz-enz and Phillips (1998:107) argue that "... retention of key employees is probably the biggest challenge in human asset management today". Labour turnover is classified in the literature as either voluntary or involuntary. Voluntary turnover is defined as employee initiated, with the staff member seeking better employment conditions or prospects or job satisfaction. Involuntary turnover is defined as employer initiated and due to retrenchment or dismissal for disciplinary or performance related reasons (P-E Corporate Services, 2001). The present research is concerned only with voluntary turnover.

\section{Antecedents of turnover}

In order to manage turnover one needs to understand its causes. There is a large body of literature on the predictive role of a large number of competing variables on labour turnover (Morrell et al., 2001). The literature reviewed points to a multiplicity of factors. Mitchell, Holtom and Lee (2001), however, find that all of the studies on antecedents to turnover leave about $75 \%$ of the variance in turnover unexplained.

Two recent large-scale studies of the literature on turnover have attempted to categorise the plethora of turnover models developed over the half century of research into attrition. The work of Morrell et al. (2001) identifies two schools of turnover research and subsequent modelling. They write firstly of the labour market school or economic school, which looks at issues such as labour supply and demand, job search theory and techniques, and objective opportunities. Work by prominent researchers such as Griffeth and Hom, Mobley, Gaertner, and Vanenberg and Nelson are classified by Morrell et al. (2001) as falling into this school. The other school of research they term "the psychological school", where issues of affect are studied; emphasis is placed on individual decision making and, in particular, the impact of job dissatisfaction and organisational commitment are studied as antecedents of turnover. Key researchers identified by Morrell et al. (2001) as falling in this school include March and Simon, Price and Mueller, and Mobley's expanded model.

The research by Rouse (2001) classifies previous research into two other groupings, namely: rational versus instinctual models. Rational models assume that employees rationally follow a linear progression towards turnover. The turnover process is viewed as beginning with the employee experiencing job dissatisfaction. Factors that determine job dissatisfaction and organisational commitment are studied and their weak, though significant, relationship to turnover together with other factors - is studied to explain the turnover phenomenon. Work by Mobley, and Steers and Mowday, are classified by Rouse (2001) as epitomising this rational school. The instinctual models assume that most people who leave an organisation are relatively satisfied with their job but typically a precipitating event - referred to as a "shock" - is the basis for departure. This body of research then examines turnover as a destination arrived at via distinct paths. Lee and Mitchell's work is defined by Rouse as being typical of this school of study.

Intention to leave is seen by many writers as the best predictor of turnover. The Corporate Leadership Council (1999) showed a strong correlation between intention to depart and actual turnover. Likewise, Maertz and Campion (2001) in their largescale analysis of turnover research find that "intention to quit" has demonstrated the most consistent bi-variate relationship to turnover behaviour with an $r$ value consistently around the 0.50 level. Many of the authors indicate the interdependence of job satisfaction, organisational commitment, and intention to leave. The Corporate Leadership Council (1999) states that the link between "employee satisfaction" and "intention to leave" is weakening as, increasingly, highly satisfied employees leave their organisation for new opportunities. Cappelli (2000) distinguishes very usefully between loyalty and commitment in the new world of work. In particular, he writes that it is a false belief that commitment can only exist in a long-term relationship.

Milkovich and Boudreau (1997) remind the reader that the decision to leave is influenced by many factors, over some of which the organisation has no control and over some of which the organisation has moderate control. The literature on specific antecedents can be divided into three sections: environmental antecedents external to the organisation; antecedents internal to the organisation and employee specific issues.

The antecedents external to the organisation lie within the labour-market approach to turnover discussed above (Cappelli, 2000). These precursors of turnover are those over which an organisation has almost no control and include: unsolicited approaches (Lee, Mitchell, Holtom, McDaniel \& Hill, 1999); labour-market influences (Maertz \& Campion, 2001); emigration caused by macro social problems (Bennett, 2003) and impacts of the Employment Equity Act (Van As, 2001).

The antecedent factors internal to the organisation over which organisations have some control are: shock events in the organisation (Allen \& Griffeth, 1999); problems with a manager (Pine \& Gilmore, 1998); pay (Milkovich \& Boudreau, 1997); lack of development opportunities (Hay, 2001) and change processes (Baron, Hannon \& Burton, 2001). 
Employee specific antecedents which are associated with individual employees' own career drivers include knowledge worker characteristics (Trevor, 2001) and family responsibilities (Milkovich and Boudreau, 1997).

\section{Consequences of turnover}

Labour turnover is also commonly classified as either functional or dysfunctional. Allen and Griffeth (1999) assert that functional turnover is characterised by a situation where high-performance employees remain with the organisation while poor performance employees leave. Van As (2001) points out that mobility can lead to organisational renewal and change, can clean out 'deadwood', making it easier to introduce new ideas, can prevent complacency, and create mobility opportunities for existing staff.

Dysfunctional turnover is characterised by high-performance employees leaving and poor performance employees staying. The literature generally reports on the dysfunctional consequences of labour turnover to the organisation. The literature on the negative consequences of attrition breaks attrition costs down into direct and indirect costs. Direct costs are those that occur in the short term after the resignation and are relatively easy to quantify. Swanepoel, Erasmus, van Wyk and Schenk (2000) assert that the direct costs of replacing an employee comprise recruitment and advertising costs, agency fees, applicant expenses, relocation expenses and all employment office expenses. Some of the components of indirect costs of turnover are: loss of knowledge (KPMG Management Consulting, 1998); productivity impacts (Michaud, 2000); lowered morale of remaining staff (Tziner \& Birati, 1996); loss of momentum in the organisation (Van As, 2001); loss of organisational memory (Hansen, Nohria \& Tirney, 1999 and Van As, 2001) and customer dissatisfaction (Koys, 2001).

It is extremely difficult to place exact estimates on the total financial impact of labour turnover, particularly as lost intellectual capital is almost unmeasurable (Fitz-enz \& Phillips, 1998). Much of the literature estimates the financial cost of the labour turnover of a knowledge worker to be equal to more than a year's salary (Michaud, 2000). The American Management Association (1997) reports the costs of the loss of a knowledge worker at between six and eighteen months salary. Branch (1998) believes the cost to be $150 \%$ of the departing person's salary. In summary, it is clear from the literature that turnover of knowledge workers in general has a large negative impact on organisations.

\section{Labour turnover rates}

The Hay study of 500,000 employees in 300 companies in 50 countries (Hay, 2001) found that employee turnover has increased by $25 \%$ in the last five years and one third of people in current employment plan to move within the next three years. Key employee turnover is running at historically high levels in South Africa. The P-E Corporate Services survey (2001) of 700 South African companies shows that the turnover rate in general has risen from $7 \%$ in 1994 to $14 \%$ in 2001.

In summary, if it is assumed from the literature that there is a $15 \%$ labour turnover amongst knowledge workers a year and that the total costs are equal to eighteen months salary, then the cost of knowledge worker turnover to an organisation is equal to $22 \%$ of the total annual salary bill for these workers. Because of these costs, Maertz and Campion (2001) suggest studies be done on the avoidability of turnover, i.e. on the means of retaining knowledge workers.

\section{Retention}

Branch (1998) contends that the objective of retention policies should be to identify and retain committed employees for as long as is profitable both to the organisation and the employee. The literature reveals that there is a multiplicity of suggested methods for retaining talent, approaching retention on many different levels, and in many different ways; as Ettore (1997: 49), notes "...at its most effective, corporate retention is a sophisticated juggling act". A worrying feature of the literature is how much of it appears anecdotal, with very few empirical studies being reported. The recommendations in the literature can be classified into three main groups:

Retention devices for the whole organisation: The suggested forms that this can take can be classified under: acceptance of increased mobility, including strategies to maintain knowledge (Olivera, 2000); and restructuring the organisation to make attrition less impactful (Cappelli, 2000).

Changing human resource systems: some of the suggested systemic human resource changes are: adjusting hiring techniques (Mengel, 2001); establishing appropriate organisational cultural and value systems (Bartlett and Ghosal, 2000) effectively utilising exit interviews and root cause analyses (Branch, 1998 and Corporate Leadership Council, 2002); identifying key roles and individuals (Cappelli, 2000); differential management of good and poor performers (Hanigan in Ettore, 1997); pay system changes (Dibble, 1999 and Gaertner, 1999); and internal branding of the employee value proposition (Chambers et al., 1998 and Sykes, 2001).

Retention devices for individuals: some of the factors seen to contribute to individual knowledge worker retention are: ensuring employability via ongoing training and development (Tulgan, 2001); performance related pay (Corporate Leadership Council, 1998b and Cappelli, 2000); increased recognition of individual contribution (Forrest, 1999); increased communication and involvement (Woodruffe, 1999 and Ruch, 2000); giving work that can be done independently (Jooste, 1997 and Wickens, 1995); giving more freedom (Kinnear and Sutherland, 2000); traditional fringe benefits (Wickens, 1995); improving the quality of management (Dobbs, 2001); attending to work/personal life balance (Ruch, 2000); giving challenging work (Harpur, 2002 and Kaye and Jordan-Evans, 2000); individual job sculpting (Butler \& Waldroop,1999); encouraging social ties (Mitchell et al., 2001); and ensuring access to leading edge technologies (Kinnear \& Sutherland, 2000).

\section{Demographic differences}

Price (1999) and Gaertner (1999) state that what is important is the identification of different management strategies for the retention of different types of employees. The Harvard Management Update (2001) also emphasises that research is needed to establish what different groups want in order to retain their services. Robbins (1998) mentions the role cultural values and lifestyle preferences play in influencing one's perception of the work environment, while Hulin, Roznowsi and Hachiya (1985) acknowledge that the perception of job alternatives and job satisfaction would be different across different employee populations.

\section{Research questions}

The literature review led to the formulation of the following research questions:

Research Question 1: What is the relationship between job satisfaction, organisational commitment and intention to leave for knowledge workers?

Research Question 2: What are the most important variables and underlying factors affecting the retention cognitions of knowledge workers?

Research Question 3: Can knowledge workers be segmented into different groupings with regard to their retention cognitions? 


\section{METHOD}

A cross-sectional pre-experimental research design (Leedy, 1997) was selected for the study. As few empirical studies investigating retention factors for knowledge workers could be found in the literature this study was exploratory in nature. The study was carried out in two phases; the first (qualitative) stage was carried out in order to elicit variables to be used in the questionnaire in the second (quantitative) phase of the study. This represents a triangulated research design (Leedy, 1997) which blends both qualitative and quantitative data measurement to allow the data to be explored from two perspectives and, in this way, increasing its construct validity.

\section{Population}

The population consists of all knowledge workers in South Africa and a sampling frame (Creswell,1994) could not be established. Brown and Duguid (1996) define a knowledge worker as a learning person. Knowledge workers are partially defined by Despres and Hiltrop (1995) as people who advance their careers through external study instead of internal training and development programmes. Armstrong and Murlis (1998) partially define the new psychological contract as one where employees rely on external, rather than internal, training and development providers. Most of the empirical studies mentioned in the preceding literature review examined single-profession samples, e.g. nurses, retail workers, and information technology employees, which greatly limited the generalisability of their findings. Thus, in order to access knowledge workers, part-time learners, all in full-time employment, at a university business school were used to represent the knowledge worker population. The uniqueness of the method of accessing some of the population used in this study was that the respondents were drawn from a broad range of industries, as is shown in the results section.

\section{Sampling}

As this is an exploratory study a judgement sample was used. This is a form of purposive sampling, which is commonly used in exploratory research (Cooper \& Schindler, 1998) where the researcher selects sample members to conform to some criterion (in this case, knowledge workers as defined above). The sample size of 306 was sufficiently large to meet the statistical test requirements for the between-group testing, cluster analysis, and factor analysis.

\section{Questionnaire construction}

For phase 1, which may be seen as a pilot study, a qualitative open-ended questionnaire was used (Cooper \& Schindler, 1998) to assist in ensuring the content validity of the ensuing questionnaire. Thirty research respondents, from the sample defined above, all of whom had changed employer within the preceding two years, were selected. The respondents were asked to recall the reasons why they left their previous employer and what that employer could have done to retain them. This data was content analysed to generate the independent variables for the research. The variables that emerge from the literature were used deductively to provide additional direction for the quantitative questionnaire for Phase 2 (Creswell, 1994). Forty two independent variables emerged from Phase 1.

The questionnaire for Phase 2 was quantitative. Biographical data was collected at the beginning of the questionnaire. The respondents were asked to record their length of service in their current organisation and how long they thought they would remain in their organisation. The respondents were asked to complete Schriesheim and Tsui's (2002) Job Satisfaction Index on a five point Likert-type scale. The next group of questions were on organisational commitment, perceived level of mobility capital, and how active the respondents were with regard to seeking other work opportunities. The respondents were then asked to rate the 42 retention variables, developed in Phase 1 of the study, on a four point Likert-type scale, noting how important each item was with regard to their intention to leave or stay with their current employer. The questionnaire was pretested and corrected for design errors.

\section{Data-gathering procedure}

The questionnaires for both phases were administered using the intercept method under controlled lecture room conditions to ensure the standardisation of data gathering, to decrease nonresponse errors, and increase response rates (Cooper \& Schindler, 1998)

\section{Limitations}

The limitations of this research are: it is a cross-sectional design that precludes a longitudinal study that might have determined causality; the sampling methodology falls under the nonprobability methods and, for this reason, the extent to which the sample represents the population cannot be claimed with confidence; the measurements rely on the perceptions of the respondents and not their actions.

\section{RESULTS AND DISCUSSION}

Three-hundred-and-six respondents completed the questionnaire. The sample composition was as follows: sixty six percent male; thirty five percent female; thirty four percent white; fifty five percent black; eight percent Asian (including Indian and Chinese respondents) and six percent coloured. They worked in all industry groups, being approximately evenly distributed over mining, manufacturing, construction, retail, hospitality, government, medical, academic, consulting and information technology organisations. Eighty percent of the respondents had at least one degree. The ages of the respondents ranged from 21 to 51 , with a mean of 32.02 and a standard deviation of 5.5. The years of service in their current organisations ranged from 0 to 24 years, with a mean of 4.11 , a median of 2.8 and a standard deviation of 4.2 , indicating a highly mobile group that is highly skewed to the bottom end of the scale. The above data indicates that a broad range of knowledge workers was used as the sample for the study. However, the sample limitations are noted.

Research question 1: What is the relationship between job satisfaction, organisational commitment, and intention to leave for knowledge workers?

Tables 1 to 7 summarise the data on the antecedents of labour turnover. The data is given in percentages with the modal category being shaded.

TABLE 1

FOR HOW MUCH LONGER DO YOU ENVISAGE WORKING FOR YOUR CURRENT ORGANISATION?

\begin{tabular}{cccccc}
\hline $\begin{array}{c}\text { Less than } \mathbf{6} \\
\text { months }\end{array}$ & $\begin{array}{c}\mathbf{6} \text { months to } \\
\text { a year }\end{array}$ & $\begin{array}{c}\mathbf{1} \text { to } \mathbf{2} \\
\text { years }\end{array}$ & $\begin{array}{c}\mathbf{3} \text { to } \mathbf{5} \\
\text { years }\end{array}$ & $\begin{array}{c}\text { More than } \\
\text { 5 years }\end{array}$ & $\begin{array}{c}\text { Until I } \\
\text { retire }\end{array}$ \\
\hline 9.5 & 16.4 & 36.7 & 24.9 & 9.5 & 3.0 \\
\hline
\end{tabular}

Table 1 shows the high mobility of the sample, in that a quarter of the group intend leaving their organisations within a year and more than $60 \%$ within two years.

\section{TABLE 2}

WHICH ONE OF THE FOLLOWING CATEGORIES BEST DESCRIBES YOUR CURRENT SITUATION?

\footnotetext{
I am not looking for another job

I occasionally look into opportunities for changing jobs
}

I am continually actively seeking another job opportunity 
Table 2 shows that the $67 \%$ of the sample were in the job market. Tables 1 and 2 indicate that the sample was in a position to record their cognitions with regard to retention. A chi-squared two variable test showed a significant dependence between Tables 1 and 2 at a significance level of 0.05 . This reflects the opinion expressed in the literature that intention to leave is highly correlated with job search activities and subsequent labour turnover (Lee at al., 1999).

\section{TABLE 3}

JOB SATISFACTION LEVELS

\begin{tabular}{|c|c|c|c|c|c|c|}
\hline $\begin{array}{l}\text { Satisfied } \\
\text { with: dis }\end{array}$ & $\begin{array}{c}\text { Very } \\
\text { ssatisfied }\end{array}$ & $\begin{array}{l}\text { Somewhat } \\
\text { dissatisfied }\end{array}$ & Neutral & Satisfied & $\begin{array}{c}\text { Very } \\
\text { satisfied }\end{array}$ & $\begin{array}{l}\text { Correlation } \\
\text { with Table }\end{array}$ \\
\hline $\begin{array}{l}\text { Nature of } \\
\text { work }\end{array}$ & 5.5 & 20.2 & 13.7 & 43.3 & 17.3 & 0.35 \\
\hline Boss & 10.7 & 20.2 & 19.5 & 29.6 & 19.9 & 0.24 \\
\hline $\begin{array}{l}\text { Peer } \\
\text { relations }\end{array}$ & 2.6 & 5.6 & 19.3 & 53.6 & 19 & 0.08 \\
\hline Pay & 13.0 & 23.8 & 22.5 & 36.5 & 4.2 & 0.26 \\
\hline $\begin{array}{l}\text { Promotion } \\
\text { opportuniti }\end{array}$ & $\begin{array}{l}18.9 \\
\text { ies }\end{array}$ & 26.1 & 20.8 & 22.5 & 11.7 & 0.36 \\
\hline $\begin{array}{l}\text { Overall } \\
\text { satisfaction }\end{array}$ & 8.5 & 23.1 & 19.5 & 40.4 & 8.5 & 0.46 \\
\hline
\end{tabular}

In comparing Tables 1, 2 and 3, it is of interest that despite high levels of satisfaction the estimated future length of service is extremely low. This is consistent with the views expressed by the Corporate Leadership Council (1999) that the link between employee satisfaction and intention to leave is weakening as increasingly highly satisfied employees leave their organisations for new opportunities. The Council is of the opinion that this de-linking is driven by: the continual perfection of the labour markets; increased visibility of employment offers from other organisations; and the reduction in switching costs from one organisation to another.

The Kendall tau correlation coefficients in Table 3 show that overall job satisfaction correlates significantly with intention to quit, although the amount of explained variance is only $21 \%$, as determined by the coefficient of variation ( $\mathrm{r}$ squared). The components of job satisfaction that correlate most highly with intention to quit are satisfaction with promotion opportunities and with the nature of work being carried out, $(\mathrm{r}=0.36$ and 0.35 respectively). This is consistent with the views of Tulgan (2001) and Kaye and Jordan-Evans (2000) that knowledge workers are preoccupied with growth opportunities and the need to be involved in exciting and challenging work.

TABLE 4

HOW COMMITTED ARE YOU TO FURTHERING THE GOALS OF YOUR EMPLOYING ORGANISATION?

\begin{tabular}{lc}
\hline Not committed & 4.9 \\
Slightly committed & 13.8 \\
Very committed & 57.0 \\
Totally committed & 24.3 \\
\hline
\end{tabular}

Again, in comparing Table 4 to Tables 1 and 2, it becomes clear that despite more than $80 \%$ of the sample seeing themselves as being very committed to the organisation, these knowledge workers don't anticipate staying in the organisation for much longer. This disparity is of interest as the literature on labour turnover traditionally views turnover as an indicator of organisational commitment. This data is consistent with Cappelli's view (2000) that loyalty and commitment are not synonyms in the new world of work. In particular, Cappelli writes that it is a false belief that commitment can only exist in long term relationships and emphasises that what is needed is commitment to the current work, rather than long-term loyalty. The correlation between organisational commitment and intention to quit is 0.32 , with the coefficient of variation showing that only $10 \%$ of the variation in intention to leave is explained by organisational commitment. The present study has shown that contrary to the views expressed in the literature, organisational commitment should not be defined as "intention to stay" for knowledge workers.

TABLE 5

HOW EASY WOULD IT BE TO FIND AN EQUIVALENT OR BETTER JOB BY THE END OF THE YEAR?

\begin{tabular}{lc}
\hline Extremely difficult & 3.9 \\
Difficult & 37.2 \\
Easy & 44.7 \\
Very easy & 14.1 \\
\hline
\end{tabular}

Table 5 indicates that the respondents perceive that they have very high movement capital, which Trevor (2001) finds to be composed of education, cognitive ability, and occupationspecific training, all of which correlate positively with turnover. Pearson (1991) termed these members of the labour market "opportunists", who are marked by their confidence and adaptability and make unplanned employer changes when offered a better deal. In summary, this part of the research showed that the relationship between job satisfaction, organisational commitment and intention to stay with one's employing organisation has been weakened in the knowledge economy. These highly mobile knowledge workers display how the psychological contract has moved on from an era where there was an emphasis on job security and loyalty to the company to an era where the emphasis is on employability and loyalty to one's own career and skills (Armstrong and Murlis, 1998).

Research question 2: What are the most important variables and factors affecting the retention cognitions of knowledge workers?

Table 6 shows, in descending order, the individual variables that the sample rated as being the most important in determining the length of their future stay with their organisation.

TABLE 6

THE MOST IMPORTANT VARIABLES AFFECTING RETENTION

\begin{tabular}{lc}
\hline Variable & Mean \\
\hline 1. Lack of challenging work & 3.53 \\
2. Your level of trust in management & 3.46 \\
3. Lack of career development opportunities & 3.42 \\
4. Incentive/bonus/variable pay & 3.37 \\
5. Base pay & 3.37 \\
6. Individual recognition \& praise being given & 3.36 \\
7. Freedom to work independently & 3.33 \\
8. Career planning by the organisation & 3.29 \\
9. Relationship with your immediate boss & 3.25 \\
10.Issues you have raised being unattended & 3.25
\end{tabular}


Table 6 supports the finding by Kinnear (1999) that independence, individualism and personal achievement are the fundamental needs of knowledge workers. She found that retention strategies should be based on freedom to act, financial rewards and recognition, development opportunities, and access to leading edge technologies. The data from this study indicates that, in addition, knowledge workers desire a high level of focus on their own career development. This is in agreement with Dobbs (2001) who asserted that knowledge workers' length of stay in an organisation is determined by their relationship with their manager. Table 7 illustrates the variables, in descending order of importance, that have the least influence on knowledge workers' decisions to stay with or leave an organisation.

TABLE 7

LEAST IMPORTANT VARIABLES IN RETENTION

\begin{tabular}{lc}
\hline Variable & Mean \\
\hline 10. Receiving an upsetting performance review & 2.54 \\
9. Upsetting organisational changes & 2.53 \\
8. Ongoing stress at work & 2.52 \\
7. Share options in the company & 2.43 \\
6. Medical aid benefits & 2.36 \\
5. Physical office environment & 2.33 \\
4. Social friendships at work & 2.20 \\
3. Distance between your home and work & 2.13 \\
2. Ease of staying in current organisation versus \\
difficulty of moving to another job
\end{tabular}

Table 7 indicates that the knowledge workers in this study are not retained as a result of factors relating broadly to personal comfort. The data confirms the futility for retention purposes of many of the current fringe benefits, such as share options and medical aid, being offered by organisations (Wickens, 1995). As Cappelli (2000:103) states: "traditional strategies for employee retention are unsuited to a world where talent runs free".

\section{Factor analysis}

In order to determine if the 42 variables could be reduced to a more meaningful set of factors that underlie the retention cognitions of knowledge workers, a factor analysis was conducted, using a principal component analysis with varimax techniques of rotation (Hair, Anderson, Tatham \& Black, 1995). After visual inspection of the scree-plot for points of inflection and an examination of the eigenvalues, a seven factor solution was selected. The cut off point of eigenvalues greater than 1.8 was used and a cut-off value of 0.4 was used on the absolute value for loading items onto factors (Hair et al., 1995). The Cronbach's alpha coefficients were calculated to test the internal reliability of the factors. The resulting factors could be logically interpreted in terms of the theory base of the study. The preceding information indicates that this is a satisfactory factor solution (Hair et al., 1995). The factors were labelled according to the items that loaded onto each factor, taking cognisance of the factor loadings. The factors are presented below.

These factors are a composite measure, or shorthand, of the retention cognitions of knowledge workers. They support the findings of the Corporate Leadership Council (1998), the Hay study (2001), and Cappelli's (2000) seminal writings. However, their findings did not look at the multivariate nature of the factors influencing knowledge workers' decisions as to whether or not to continue in employment with their current organisation. The factors are rank-ordered in Table 15 according to their factor means in order to determine their relative importance.

TABLE 8

FACTOR 1

\begin{tabular}{ll}
\hline Eigenvalue 2.97 & Cronbrach's alpha 0.67 \\
\hline Factor loading & Questionnaire item \\
\hline-0.67 & Company strategy problems \\
-0.61 & Company reputation \\
-0.55 & Organisations general culture \\
-0.49 & The performance appraisal process \\
-0.46 & Communication problems \\
-0.43 & internally \\
\hline
\end{tabular}

Factor label: Organisational setting

Table 9

FACTOR 2

\begin{tabular}{ll}
\hline Eigenvalue 3.02 & Cronbrach's alpha 0.70 \\
\hline Factor loading & Questionnaire item \\
\hline 0.60 & Distance between work and home \\
0.58 & Ease of staying versus difficulty of going \\
0.50 & Ongoing stress at work \\
0.50 & Work versus personal life balance \\
0.47 & Job security at present organisation \\
0.45 & Physical office environment \\
0.43 & Medical aid benefits \\
0.42 & Fitting into the culture in terms of race, age and gender \\
\hline Factor label: Personal comfort
\end{tabular}

TAble 10

FACTOR 3

\begin{tabular}{ll}
\hline Eigenvalue 3.39 & Cronbrach's alpha 0.70 \\
\hline Factor loading & Questionnaire item \\
\hline 0.66 & Issues you raised being unattended \\
0.54 & Job not being designed around your needs \\
0.53 & Lack of challenging work \\
0.51 & Individual recognition and praise being given \\
0.51 & Your ideas being ignored \\
0.43 & Your level of commitment to the organisation \\
0.43 & Company structure problems \\
0.42 & Communication problems internally \\
\hline
\end{tabular}

Factor label: Egocentricity and challenge within the organisation 
TABLE 11

FACTOR 4

\begin{tabular}{ll}
\hline Eigenvalue 1.86 & Cronbrach's alpha 0.55 \\
\hline Factor loading & Questionnaire item \\
\hline 0.73 & To change your field of work \\
0.59 & Your need to work in a different type of company \\
\hline
\end{tabular}

Factor label: Desire for a change in career

TABLE 12

FACTOR 5

\begin{tabular}{ll}
\hline Eigenvalue 2.25 & Cronbrach's alpha 0.56 \\
\hline Factor loading & Questionnaire item \\
\hline-0.69 & The salary increase system \\
-0.60 & Short term promotion opportunities \\
-0.44 & Incentives/Bonus/Variable pay \\
-0.43 & Base Pay \\
-0.42 & The performance appraisal process \\
-0.41 & Being offered a job by another organisation
\end{tabular}

Factor label: Performance related rewards

TABLE 13

FACTOR 6

\begin{tabular}{ll}
\hline Eigenvalue 1.86 & Cronbrach's alpha 0.3738 \\
\hline Factor loading & Questionnaire item \\
\hline-0.61 & Freedom to work independently \\
-0.59 & Incentive/Bonus/Variable pay \\
\hline
\end{tabular}

Factor label: Independence

TABLE 14

FACTOR 7

\begin{tabular}{ll}
\hline Eigenvalue 2.26 & Cronbach's alpha 0.54 \\
\hline Factor loading & Questionnaire item \\
0.66 & Career planning by the organisation \\
0.60 & Training provided by the organisation \\
0.48 & Lack of career development opportunities \\
0.41 & Your level of trust in management
\end{tabular}

Factor label: Career development support by the organisation

The mean scores in Table 15 indicate that the first five retention factors are considered to be important to knowledge workers as they each have a mean of over 3 while the last two are relatively unimportant. There is also a 0.44 jump in the differences between the means between the fifth and sixth factors, whereas all the other differences are 0.1 or less. The table confirms Armstrong and Murlis' (1998) assertion that, in terms of the new psychological contract, employees have the right to demand interesting and important work, the freedom and resources to perform it well, receive pay that reflects their contribution, and to get training and experience needed to be employable in "this" or another organisation. The data indicates a "me generation" in which egocentricity is the norm.

\section{TABLE 15}

\section{RELATIVE IMPORTANCE OF THE RETENTION FACTORS}

\begin{tabular}{lcl}
$\begin{array}{l}\text { Factor the } \\
\text { mean on } \\
\text { 4-point } \\
\text { scale }\end{array}$ & $\begin{array}{c}\text { Factor } \\
\text { number }\end{array}$ & Factor label \\
\hline 3.35 & 6 & Independence \\
3.28 & 7 & Career development support by organisation \\
3.18 & 3 & Egocentricity and challenge within the organisation \\
3.11 & 1 & Organisational setting \\
3.07 & 5 & Performance related rewards \\
2.63 & 4 & Desire for a career change \\
2.42 & 2 & Personal comfort \\
\hline
\end{tabular}

Research question 3: Can knowledge workers be segmented into different groupings with regard to their retention cognitions?

\section{Demographic differences}

The first set of statistical analyses looked for between-group differences on the 42 individual retention items, using a significance level of 0.05. Of the 42 Mann Whitney U tests done on the retention variables for gender differences, only six significant differences were found. The 42 Kruskal-Wallis Analyses of Variance, performed to examine differences between race groups, showed only seven significant differences. The 42 Kruskal-Wallis tests performed on the three age categories revealed only three items with significant differences. The 42 Kruskal-Wallis tests revealed only four significant differences between the various industry groupings. In summary, of the 168 hypotheses tested, only 20 significant differences were found. Hence the sample cannot be segmented on the basis of individual variables and singular demographic variables. A multivariate basis was thus used to segment the sample.

\section{Multivariate segmentation}

A cluster analysis was conducted in order to explore the data set for the definition of subgroups of homogeneous individuals (Hair et al., 1995). The K-means analysis revealed nine clusters. The distribution of respondents between the clusters varied from 11 to 49 respondents with a mean of 31.88 . The F-ratio test rejected the null hypothesis at the 0.01 significance level, showing the clusters to be independent of one another with significantly different cluster means. The clusters explain $78.36 \%$ of the variance in the data. Hence, a satisfactory cluster solution was determined (Hair et al., 1995). The clusters are described in Tables 16 to 24, each of which gives:

- the number of respondents in the cluster;

- the retention factors that the cluster significantly differs from, as defined by a z-score of greater than an absolute value of 1 , which gives the cluster its characteristic identity;

- the identifying profile of the respondents in the cluster as defined by the variables that were shown via two variable chisquared tests of dependence to significantly identify the cluster members, the variables being race, gender, satisfaction with the nature of work, envisaged future stay with the organisation, age, academic course being studied, the level of importance they place on fitting into the organisational culture and their level of job search activity; and, finally,

- the cluster label based on the two preceding identifying profiles. 
TABLE 16

CLUSTER $1 \mathrm{~N}=38$

\begin{tabular}{ll}
\hline Cluster characteristic: & $\begin{array}{l}\text { Cluster label: } \\
\text { Salon culture }\end{array}$ \\
$\begin{array}{l}\text { These respondents have an unusually high desire } \\
\text { for personal comfort. }\end{array}$ \\
\hline $\begin{array}{l}\text { Respondent identity: These are mainly women and respondents for whom } \\
\text { fitting into the organisational culture is extremely important }\end{array}$
\end{tabular}

TABLE 17

Cluster 2 N $=36$

\begin{tabular}{ll}
\hline Cluster characteristic: & $\begin{array}{l}\text { Cluster label: } \\
\text { The seekers }\end{array}$ \\
These respondents are driven by an above average & \\
need for a career change. & \\
\hline
\end{tabular}

Respondent identity: These are mainly young respondents planning to leave their organisation in less than a year and who are dissatisfied with many aspects of their current job. They are actively looking for jobs.

\section{TABLE 18}

Cluster 3 N $=42$

Cluster characteristic:

These respondents are not driven by a need for individualism.

Respondent identity: These are mainly young respondents who are largely coloured and Asian.

TABLE 19

\section{Cluster 4 N $=33$}

Cluster characteristic:

These respondents place less importance on individualism,

performance related rewards and don't look to the organisation to develop them.

Respondent identity: These are respondents planning to leave the organisation in less than six months.

\section{TABLE 20}

Cluster 5 N $=24$

Cluster characteristic:

Cluster label:

The self-sufficient

These respondents do not want to change their careers and have very low need for personal comfort.

Respondent identity: These are mainly white respondents who aren't planning to change jobs. They are not concerned with fitting into the organisational culture.

\section{TABLe 21}

\section{Cluster 6 n=11}

Cluster characteristic:

This handful of respondents are extreme outliers in their rejection of concern about the organisation and their rejection of egocentricity. Furthermore they aren't concerned with individualism or personal comfort.

Respondent identity: These respondents mainly plan to leave in less than a year. They are characterised by being unhappy with the pay they are receiving.
TABLE 22

Cluster $7 \mathrm{~N}=48$
Cluster label:

Contended new agers
This group of respondents represents the average

knowledge worker as described in the factor analysis,

with a slightly above average concern for looking

after their own needs

Respondent identity: These are respondents who are satisfied with the nature of the work they perform and plan to stay in the organisation in the medium term. They are over represented by coloured and Asian respondents

TABLE 23

Cluster 8 N $=49$

Cluster characteristic:

Cluster label:

The co-dependants

These respondents have a high organisational

dependency on all 3 factors relating to the organisation.

Respondent identity: These are mainly black respondents studying on the MAP programme who feel that fitting into the organisation's culture is extremely important

TABLE 24

Cluster 9 N $=26$

\section{Cluster characteristic:}

Cluster label:

This group of respondents does not expect the

The self starters

This group of respondents does not expect
organisation to take responsibility for their development

Respondent identity: These are chiefly young male MBA respondents.

The clusters in Tables 16 to 24 show that knowledge workers in this sample are not a homogeneous population, but comprise sub-groupings that have distinct identities. This supports Wickens' view (1995) that companies need to appeal to unique and individual value systems rather than provide generic motivators. Although some literature discusses the need to understand differing retention requirements (Harvard Management Update, 2001) and the fact that one's life experience may influence one's work cognitions (Robbins, 1998), no empirical evidence of such information could be found. Clearly, this exploratory research is but the basis for the development and validation of further psycho-graphic profiles that could assist organisations to respond fully to the range of aspirations that their knowledge workers have.

\section{Recommendations}

The transformation to the knowledge era, and the consequent changes in the psychological contract between employer and employee, has resulted in retention of knowledge workers being a key issue in management today. Recommendations on retention that emerge from the findings of this study are listed below under three major stakeholder groups.

\section{Recommendations to management}

The literature review and the data from this sample indicate that managers and human resource managers in particular, need to understand that: high levels of knowledge worker mobility are a defining characteristic of the knowledge based economy; the costs associated with this mobility and the benefits of reducing labour turnover via employing retention strategies are significant; high levels of employee commitment can be achieved but not long term loyalty. As Cappelli (2000:105) writes, "you are managing a river not a dam", i.e. managers should adapt to a continual flow of people through the 
organisation. This implies that organisations should develop a high level of competence in attracting and selecting competent knowledge workers. They should also ensure the continual transfer and encoding of knowledge, so that in the event of a knowledge worker leaving, their knowledge is retained by the organisation. The data suggests the organisations need to develop and communicate compelling employee propositions that highlight the availability of challenging work, career development opportunities, as well as rewards based on individual performance.

\section{Recommendations to academics}

This research has begun to develop an understanding of the complexity of the drivers of mobility amongst knowledge workers. What is evident is that the new world of work is fruitful ground for empirical research into the defining characteristics of knowledge workers. In particular, this research suggests to fellow academics that the old theories may no longer hold; job satisfaction and organisational commitment do not necessarily lead to loyalty, long defined as the intention to remain with an employer. The psychological contract has changed profoundly, with concomitant spin-offs that need to be fully researched. The data shows that knowledge workers have defining overarching characteristics and can be further segmented into meaningful sub-groupings, each with its own defining characteristics. These factors need to be further researched so that management theories and practices for the knowledge era could be built on an empirical basis.

\section{Recommendations for knowledge workers}

This research has implications for the way knowledge workers manage their careers. They need to understand that this is the age of self determination. They must create their own futures by continuously developing their employability via further education and developing new, labour-market related competences.

\section{Conclusion}

This research set out to understand the mobility of knowledge workers, which is a defining characteristic of the new world of work. The retention cognitions of a large sample of these employees were established, supplying information on the high level of individualism, the need for challenge and the career management desires of this new breed of worker. This study may contribute to the understanding organisations and academics have of more effective methods for managing knowledge workers, who are unique and increasingly important contributors to the knowledge based economy.

\section{REFERENCES}

Allen, D.G. \& Griffeth, R.W. (1999). Job performance and turnover: A review and integrative multi-route model. Human Resource Management Review, 9 (4), 525-548.

American Management Association. (1997). Retention management strategies, practices, trends. New York: Saratoga Institute.

Armstrong, M. \& Murlis, H. (1998). Reward management. London: Biddles Ltd.

Baron, J.N, Hannan, M.T. \& Burton, M.D. (2001). Labor pains: change in organisational models and employee turnover in young, high-tech firms. American Journal of Sociology, 106 (4), 960-1010.

Bartlett, C. \& Ghosal, S. (2000) Competing on human capital. Book in progress. http://www.linezine.com/4.2/articles/ chsghebip.htm accessed 12/02/03

Bennett, J. (2003). Employers have their work cut out. Sunday Times. Business Times. March 16. Johannesburg, 1.

Branch, S. (1998). You hired 'em. But can you keep 'em? Fortune Magazine, November 9, 101-104.
Brown, J.S. \& Duguid, P. (1996). Organisational learning and communities-of-practice. In: Cohen, M.D. \& Sproull, L.S. (Eds). Organisational learning. California: Sage Publications.

Bussin, M. (2002). Retention strategies: remuneration answers. Johannesburg: Knowledge Resources.

Butler, T. \& Waldroop, J. (1999). Job sculpting. The art of retaining your best people. Harvard Business Review, September-October, 144-152.

Cappelli, P. (2000). A market driven approach to retaining talent. Harvard Business Review, January-February, 103-111.

Chambers, E.G., Foulon, M., Handfield-Jones, H., Hankin, S.M. \& Michaels, E.G.III (1998). The war for talent. The McKinsey Quarterly, (3), 44-57.

Cooper, D.R. \& Schindler, P.S. (1998). Business research methods Boston: McGraw-Hill.

Corporate Leadership Council (1998a) Crafting a "compelling offer". Preliminary results from primary research into the career decisions of high value employees. Washington DC: The Corporate Advisory Board.

Corporate Leadership Council (1998b). Addressing systematic drivers of dissatisfaction. Washington DC: The Corporate Advisory Board.

Corporate Leadership Council (1999). Salient findings on career decisions of high value employees. Washington DC: The Corporate Advisory Board.

Corporate Leadership Council (2002). Follow-Up on exit interview data. March. Washington DC: The Corporate Advisory Board.

Creswell, J.W. (1994). Research design, qualitative \& quantitative approaches. London: Sage.

Despres, C. \& Hiltrop, J.M. (1995). Human resource management in the knowledge age: current practices and perspectives on the future. Employee Relations, 17 (1), 9-23.

Dibble, S. (1999). Keeping your valuable employees. New York: John Wiley.

Dobbs, K. (2001). Knowing how to keep your best and your brightest. Workforce, April, 57-60.

Drucker, P.F. (1974). Management. London: Heinemann.

Drucker, P.F. (1989). The new realities. Oxford: Heinemann Professional Publishing.

Drucker, P.F. (2002). They're not employees, they're people. Harvard Business Review, February, 70-77.

Ettore, B. (1997). How are companies keeping the employees they want. Management Review, 86 (5), 49-53.

Fitz-enz, J. \& Phillips, J.J. (1998). A new vision for human resources. Menlo Park: Crisp Management Library.

Forrest, D. (1999). The foundation of employee retention. http://www.keeping employees.com/WhitePapers/attitude accessed 12/02/03

Friedman, B. Hatch, B. \& Walker, D.M. (1998). Delivering on the promise. New York: The Free Press.

Gaertner, S. (1999). Structural determinants of job satisfaction and organisational commitment in turnover models. Human Resource Management Review, 9 (4), 479-493.

Hair, F., Anderson, R.E., Tatham, R.L. \& Black, W.C. (1995). Multivariate Data Analysis. New Jersey: Prentice Hall.

Hansen, M.T., Nohria, N. \& Tierney, T. (1999). What's your strategy for managing knowledge? Harvard Business Review, March-April, 106-116.

Harpur, A. (2002). Retention factors affecting knowledge workers in the financial services sector. Unpublished MBA project report. Johannesburg: University of the Witwatersrand.

Harrigan, K.R. \& Dalmia, G. (1991). Knowledge workers: the last bastion of competitive advantage. Planning Review, November - December, 19(6), 4-11.

Harvard Management Update (2001). A new retention strategy: focusing on individuals. Harvard Business School Publishing, 6 (1), 2-4

Hay, M. (2001). Strategies for survival in the war of talent. Career Development International, 7 (1), 52-55.

Hulin, C.L., Roznowsi, M. \& Hachiya, D. (1985). Alternative opportunities and withdrawal decisions: Empirical and theoretical discrepancies and an integration. Psychological Bulletin, 97, 233-250. 
Jooste, A. (1997). New strategic questions for the knowledge age. In: Duffy, N., Jooste, A. \& Whittaker, 1. (Eds.). Leveraging knowledge for business performance. Proceedings of the first South African knowledge management conference, (pp.83-105). Johannesburg: University of the Witwatersrand.

Kaye, B. \& Jordan-Evans, S. (2000). Retention: tag, you're It! Training \& Development, April, 29-33.

Kinnear, L. (1999). Determinants of organisational commitment amongst knowledge workers. Unpublished Master of Management research report. Johannesburg:

University of the Witwatersrand.

Kinnear, L. \& Sutherland, M. (2000). Determinants of organisational commitment amongst knowledge workers. South African Journal of Business Management, 31 (3), 106112.

Koys, D.J. (2001). The effects of employee satisfaction, organisational citizenship behaviour, and turnover on organisational effectiveness: A unit-level, longitudinal study. Personnel Psychology, 54, 101-139.

KPMG Management Consulting. (1998). Knowledge Management Research Report. KPMG.

Lee, G. (2001). Towards a contingent model of key staff retention: The new psychological contract reconsidered. South African Journal of Business Management, 32 (1), 1-9.

Lee, T.W., Mitchell, T.R., Holtom, B.C., McDaniel, L.S. \& Hill, J.W. (1999). The unfolding model of voluntary turnover: A replication and extension. Academy of Management Journal, 42 (4), 450-462.

Leedy, P. (1997). Practical research planning and design. New Jersey: Prentice Hall.

Maertz, C.P. \& Campion, M.A. (2001). Turnover. In: Robertson, I. \& Cooper, C. Personnel psychology and HRM. New York: John Wiley.

Mengel, D. (2001). Top ten ways to retain high performance employees. HR Future. August, 7.

Michaud, L. (2000). The value of retaining employees. Agency Sales Magazine, 30 (11), 25-27.

Milkovich, G.T. \& Boudreau, J.W. (1997). Human resource management. Chicago: Irwin.

Mitchell, T.R., Holtom, B.C. \& Lee, T.W. (2001). How to keep your best employees: developing an effective retention policy. Academy of Management Executive, 15 (4), 96-107.

Morrell, K., Loan-Clarke, J. \& Wilkinson, A. (2001). Unweaving leaving: The use of models in management of employee turnover. International Journal of Management Review, 3 (3) 219-244.

Olivera, F. (2000). Memory systems in organisations: An empirical investigation of mechanismsfor knowledge collection, storage and access. Journal of Management Studies, 37 (6), 811-832.

Paul, D. (editor). (2000). The best companies to work for in SA. Cape Town: Zebra Press.

Pearson, R. (1991). The human resource. Berkshire: McGraw Hill.

P-E Corporate Services (2001). Human resources practitioners handbook. Johannesburg: P-E Corporate Services.

Pine, B.J. \& Gilmore,J.H. (1998). Welcome to the experience economy. Harvard Business Review, July-August, 97-105.

Price, J.L. (1999). Introduction to the special issue on employee turnover. Human Resource Management Review, 9 (4), 387-395.

Robbins, S.P. (1998). Organisational behaviour. New Jersey: Prentice Hall.

Rouse, P.D. (2001). Voluntary turnover related to information technology professionals: A review of rational and instinctual models. The International Journal of Organisational Analysis, 9 (3), 281-290.

Ruch, W. (2000). How to keep Gen X employees becoming XEmployees. Training \& Development, April, 40-45.

Schriesheim, C. \& Tsui, A.S. (2002). Development and validation of a short satisfaction instrument for use in survey feedback interventions. In: Fields, D.L. Taking the measure of work; A guide to validated scales for organisational research and diagnosis. London: Sage.

Sykes, A. (2001). You can retain staff without paying them more. HR Future, August, 38.

Swanepoel, B., Erasmus, B., van Wyk, M. \& Schenk, H. (2000). South African human resource management: theory and practice. Kenwyn: Juta \& Co.

Templer, A.J. \& Cawsey, T.F. (1999). Rethinking career development in the era of portfolio careers. Career Development International, 4 (2), 70-76.

Trevor, C.O. (2001). Interactions among actual ease-ofmovement determinants and job satisfaction in the prediction of voluntary turnover. Academy of Management Journal, 44 (4), 621-638.

Tulgan, B. (2001). Winning the talent wars. New York: Norton \& Company.

Tziner, A. \& Birati, A. (1996). Assessing employee turnover costs: A revised approach. Human Resource Management Review, 6 (2), 113-122.

Van As, D.S. (2001). Executive mobility in a manufacturing environment. Unpublished MBA project report Johannesburg: University of the Witwatersrand.

Wickens, P.D. (1995). The ascendant organisation. London: MacMillan.

Woodruffe, C. (1999). Winning the talent war. Chichester: John Wiley. 